\title{
HUBUNGAN PENGGUNAAN KONTRASEPSI HORMONAL DENGAN JUMLAH PERDARAHAN MENSTRUASI SAAT MENSTRUASI DI RUMAH BERSALIN SRI NIRMALA
}

\author{
Muslihati ${ }^{1}$, Bina Melvia Girsang ${ }^{2}$, Herliawati ${ }^{3}$ \\ 1,2,3 Program Studi IImu Keperawatan FK UNSRI \\ Email: famuslihati@yahoo.com
}

\begin{abstract}
The hormonal contraception contains estrogen and progesterone. Hormonal contraception methods has a significant correlation with menstrual bleeding amount. The contributing factors were age, nutritional status, physical activity, and stress. This study aimed to determine the relationship between the hormonal contraception with the menstrual bleeding amount in Sri Nirmala Hospital. The study design was descriptive analytic. The sample size was 89 respondents. The study results showed that the majority of respondents used injection contraceptive method (55.1\%); experienced abnormal menstrual bleeding (60.7\%); age <40 years old (65.2\%); normal nutritional status (62.9\%); active physical activity (61.8\%); experienced stress (61.8\%). Menstrual bleeding amount was measured using a digital scale portable scale SF-400 during the 1st and 2nd day of menstruation. There was a significant relationship between hormonal contraception use $(p=0.026)$, age $(p=0018)$, nutritional status $(p=0.007)$, physical activity $(p=0016)$, and stress $(p=0016)$ with menstrual bleeding amount. The hormonal contraceptive method has a significant correlation with menstrual bleeding amount.
\end{abstract}

Keywords : Hormonal Contraception, Bleeding

\begin{abstract}
ABSTRAK
Kontrasepsi hormonal mengandung hormon dari estrogen dan progesteron. Metode kontrasepsi berkaitan erat dengan jumlah perdarahan menstruasi. Faktor lain yang mempengaruhi jumlah perdarahan menstruasi adalah umur, status gizi, aktivitas fisik, dan stress. Penelitian ini bertujuan untuk mengetahui hubungan kontrasepsi hormonal dengan jumlah perdarahan menstruasi di Rumah Bersalin Sri Nirmala. Desain yang digunakan dalam penelitian ini adalah Deskriptif Analitik. Jumlah sampel sebanyak 89 orang. Analisa data menunjukkan sebagian besar responden merupakan pengguna kontrasepsi suntik (55.1\%); jumlah perdarahan menstruasi tidak normal $(60.7 \%)$; umur < 40 tahun $(65.2 \%)$; status gizi normal (62.9\%); aktivitas fisik aktif (61.8\%); stress (61.8\%). Pengukuran jumlah perdarahan menstruasi dilakukan dengan menggunakan alat timbangan digital portable scale SF-400 pada hari ke 1 dan 2 menstruasi. Terdapat hubungan yang bermakna antara kontrasepsi hormonal $(p=0.026)$, umur $(p=0.018)$, status gizi $(p=0.007)$, aktivitas fisik $(p=0.016)$, dan stress $(p=0.016)$ terhadap jumlah perdarahan menstruasi. Kesimpulan penelitian terdapat hubungan yang signifikan antara penggunaan kontrasepsi hormonal dengan jumlah perdarahan menstruasi

Kata Kunci : Kontrasepsi Hormonal; Perdarahan menstruasi
\end{abstract}




\section{PENDAHULUAN}

Pertumbuhan penduduk yang cepat terjadi karena mulai tingginya angka laju pertumbuhan penduduk (UNFPA, 2014). Laju pertumbuhan penduduk di Indonesia dapat dikendalikan dengan mengontrol faktorfaktor yang mempengaruhi pertumbuhan penduduk yaitu melalui keluarga berencana untuk mengendalikan fertilitas (BKKBN, 2015). Keluarga Berencana merupakan program yang meningkatkan peran dan kepedulian masyarakat melalui pengaturan jumlah dan jarak kelahiran dengan berbagai macam metode kontrasepsi yang telah tersedia.

Kontrasepsi yaitu pencegahan terbuahinya sel telur oleh sel sperma (konsepsi) (Nugroho \& Utama, 2014). Metode KB dibagi menjadi 2 yaitu kontrasepsi hormonal (pil, implant, suntik) dan kontrasepsi non-hormonal Intra Uterine Device (IUD), Metode Operasi Wanita (MOW), dan Metode Operasi Pria (MOP), dan kondom (BKKBN, 2004). Metode kontrasepsi berkaitan erat dengan siklus menstruasi. Siklus menstruasi rata-rata berlangsung selama dalam 24-35 hari sekali, lamanya 3-7 hari dengan jumlah darah haid 33,2 $\pm 16 \mathrm{cc}$ atau tidak lebih dari $60-80 \mathrm{ml}$, dan frekuensi ganti pembalut 2-6 kali perhari (Prawirohardjo, 2011).

Penggunaan kontrasepsi telah meningkat di Asia dari 60,9\% menjadi 61,6\% sedangkan Amerika Latin dan Karibia naik sedikit dari $66,7 \%$ menjadi $67,0 \%$ dan terendah di Sub-Sahara Afrika dari $23,6 \%$ menjadi $27,6 \%$ (WHO, 2014). Di Indonesia jumlah PUS peserta KB aktif tercatat sebanyak 6.847 .080 peserta dengan KB suntik $52,21 \%$, pil $24,36 \%$, dan implan 9,73\% (BKKBN, 2015). Di Sumatera Selatan dari awal JanuariOktober jumlah PUS yang KB aktif tercatat sebanyak 215.943 peserta dengan KB suntik $35,28 \%$, pil $23,75 \%$, dan implan $15,36 \%$, sedangkan di Kecamatan Kalidoni dari Januari-Oktober 2016 dengan rincian dengan jumlah PUS yang KB aktif tercatat sebanyak 14.141 peserta, KB dengan metode KB suntik $29,32 \%$, pil $27,53 \%$, dan implan $12,64 \%$ (Badan Keluarga Berencana \& Pemberdayaan Perempuan Kota Palembang, 2016). Angka penggunaan kontrasepsi hormonal di Indonesia cukup tinggi.

Kontrasepsi hormonal adalah alat atau obat untuk mencegah terjadinya kehamilan mengandung preparat estrogen dan progesteron. Kedua hormon-hormon tersebut bekerja sebagai penghambat pengeluaran folicel stimulating hormon dan leitenizing hormon sehingga menghambat proses konsepsi (Manuaba, 2002). Kontrasepsi pil mengandung estrogen dan progesteron untuk menurunkan durasi dan jumlah perdarahan menstruasi, tetapi masih menimbulkan perdarahan intermiten. Kontrasepsi suntik mengandung progestin yang membatasi pola perdarahan berhubungan dengan tidak teraturnya menstruasi (amenorrhea) (Kusmiran, 2010). Kontrasepsi implan memiliki kadar estrogen rendah sehingga rata-rata jumlah darah yang keluar saat menstruasi lebih sedikit (Wikjosastro, 2007).

Pemakaian kontrasepsi hormonal rata-rata jumlah darah yang keluar biasanya lebih banyak dan bisa berdampak anemia berat (BKKBN, 2011). Tetapi jika awal saat haid darah yang keluar jumlahnya lebih sedikit tiba-tiba darah yang keluar jumlahnya menjadi banyak kemungkinan lain terjadi kejang rahim (uterine cramp) (Glassier Gebbie, 2005). Berbagai faktor mempengaruhi jumlah perdarahan menstruasi pada akseptor kontrasepsi hormonal. Faktor 
yang mempengaruhi adalah umur, status gizi, aktifitas fisik, dan stres (Pratiwi, 2013). Rentang umur awal dan akhir masa reproduktif (18-55 tahun) mengalami perubahan fisik dan psikologis serta berkurangnya kemampuan reproduktif (Hurlock, 1999) sampai timbulnya tanda-tanda menopause (Smart, 2010). Status gizi akan mempengaruhi metabolisme hormon estrogen pada sistem reproduksi wanita (Caroline, 2001). Melakukan aktivitas fisik yang terlalu berat menyebabkan tubuh stres hingga merusak kualitas sel-sel reproduksi (FKUI, 2012). Faktor stress, hormon stress yaitu kortisol mempengaruhi jumlah esterogen dan progesteron dalam tubuh, jika jumlah hormon yang terlalu banyak dalam darah bisa menyebabkan perubahan siklus menstruasi (Pratiwi, 2013).

Studi pendahuluan yang dilakukan peneliti di Rumah Bersalin Sri Nirmala, Kalidoni didapatkan data bahwa jumlah akseptor kontrasepsi hormonal pada Januari-Oktober 2016 dengan KB suntik sebanyak 1312 akseptor, pil 161 akseptor, dan implan 103 akseptor. Selain itu, hasil observasi dan wawancara yang dilakukan peneliti didapatkan bahwa 5 responden KB Suntik mengalami menstruasi $>3$ bulan (amenorea) atau perdarahan tidak teratur, 5 responden KB Pil mengalami perdarahan bercak dengan perdarahan tidak teratur sedangkan 5 akseptor KB Implan mengalami perdarahan bercak bahkan ada yang terjadi peningkatan jumlah darah menstruasi.

\section{METODE PENELITIAN}

Penelitian ini merupakan penelitian kuantitatif dengan rancangan penelitian deskriptif analitik. Metode yang digunakan dalam pengambilan sampel untuk penelitian ini adalah nonprobability sampling method dengan teknik purposive sampling. Jumlah sampel sebanyak 89 orang responden. Pelaksanaan penelitian dilakukan pada tanggal 4 Desember-20 Desember 2016 di wilayah sekitar Kecamatan Kalidoni meliputi beberapa desa di Kecamatan Kalidoni. Alat pengumpulan data yang digunakan dalam penelitian ini adalah pengukuran IMT (Indeks Massa Tubuh), pengukuran jumlah perdarahan menstruasi di pembalut saat menstruasi dengan timbangan digital portable scale SF-400, dan kuisioner DASS (Depression Anxiety Stress Scale) dalam menganalisa tingkat stress pada ibu yang menggunakan kontrasepsi hormonal. Analisa data yang digunakan dalam penelitian ini adalah analisa data univariat dan bivariat. Analisa data univariat dilakukan untuk mengetahui jumlah perdarahan menstruasi dan faktor lain pada pengguna kontrasepsi hormonal. Sedangkan analisa data bivariat dilakukan untuk mengetahui hubungan penggunaan kontrasepsi hormonal dan faktor lain dengan jumlah perdarahan menstruasi saat menstruasi menggunakan uji chi-square.

\section{HASIL DAN PEMBAHASAN}

Berdasarkan hasil analisis didapatkan bahwa responden terbanyak mengalami jumlah perdarahan menstruasi tidak normal sebanyak 54 orang $(60.7 \%)$. Penelitian ini dilakukan pengukuran jumlah darah menstruasi di pembalut menggunakan timbangan digital portable scale SF-400 selama 1-2 hari pada setiap 6 jam sekali selama 24 jam (4 kali ganti pembalut). Didapatkan 25 responden KB suntik dengan rentang 23$34 \mathrm{ml}$ mengalami darah yang keluar pada 6 bulan penggunaan atau perdarahan tidak teratur, sedangkan pada 17 responden $\mathrm{KB}$ pil dengan rentang 18-32 


\section{Karakteristik Responden}

Tabel 4.1

Distribusi Frekuensi Jumlah perdarahan menstruasi, Kontrasepsi Hormonal, dan Faktor Lain Responden Menurut Umur, Status Gizi, Aktivitas Fisik, dan Stress

\begin{tabular}{|c|c|c|}
\hline Variabel & Frekuensi (Orang) & Persentase (\%) \\
\hline \multicolumn{3}{|c|}{ Kontrasepsi Hormonal } \\
\hline Suntik & 49 & 55.1 \\
\hline Pil & 25 & 28.1 \\
\hline Implan & 15 & 16.9 \\
\hline Jumlah & $n=89$ & 100 \\
\hline \multicolumn{3}{|l|}{ Faktor Lain } \\
\hline \multicolumn{3}{|l|}{ Umur } \\
\hline$<40$ tahun & 58 & 65.2 \\
\hline$\geq 40$ tahun & 31 & 34.8 \\
\hline Jumlah & $n=89$ & 100 \\
\hline \multicolumn{3}{|l|}{ Status Gizi } \\
\hline Normal & 56 & 62.9 \\
\hline Tidak Normal & 33 & 37.1 \\
\hline Jumlah & $n=89$ & 100 \\
\hline \multicolumn{3}{|l|}{ Aktivitas Fisik } \\
\hline Tidak Aktif & 34 & 38.2 \\
\hline Aktif & 55 & 61.8 \\
\hline Jumlah & $n=89$ & 100 \\
\hline \multicolumn{3}{|l|}{ Keadaan Stress } \\
\hline Stress & 55 & 61.8 \\
\hline Normal & 34 & 38.2 \\
\hline Jumlah & $\mathrm{n}=89$ & 100 \\
\hline \multicolumn{3}{|l|}{$\begin{array}{l}\text { Jumlah perdarahan } \\
\text { menstruasi }\end{array}$} \\
\hline $\begin{array}{l}\text { Normal: } \\
60-80 \mathrm{ml}\end{array}$ & 35 & 39.3 \\
\hline $\begin{array}{l}\text { Tidak normal: } \\
<60 \mathrm{ml} \text { atau }>80 \mathrm{ml}\end{array}$ & 54 & 60.7 \\
\hline Jumlah & $n=89$ & 100 \\
\hline
\end{tabular}

$\mathrm{ml}$ mengalami perdarahan bercak secara intermiten dan 12 responden KB implan dengan rentang 20-45 $\mathrm{ml}$ dan $82-84 \mathrm{ml}$ mengalami perdarahan bercak atau bahkan ada yang terjadi peningkatan jumlah darah haid ditandai dengan darah yang mengumpal.

Penelitian ini sejalan dengan penelitian yang dilakukan oleh Anggia (2012), pada kontrasepsi hormonal dengan hasil 23 responden $(27,7 \%)$ mengalami ketidakteraturan menstruasi yang tidak normal berupa pola menstruasi sebanyak 22 responden (25,9\%) mengalami perubahan menjadi tidak menstruasi >3 bulan (amenorea), bercak darah (spotting) dialami oleh 6 responden $(7,1 \%)$ dan 22 responden $(25,9 \%)$ tidak menstruasi.

Berdasarkan hasil analisis didapatkan bahwa responden terbanyak yaitu KB suntik salah satunya suntik depo medroxy progesterone asetat sebanyak 49 orang $(55.1 \%)$. Hal ini sejalan dengan 
penelitian Sulistyawati (2013), suntik DMPA yaitu tidak mengandung estrogen sehingga tidak berdampak penyakit jantung dan gangguan pembekuan darah, efek samping sangat kecil, dapat digunakan oleh perempuan usia lebih 35 tahun sampai perimenopause. Menurut pendapat peneliti, kontrasepsi hormonal banyak mendapat pengaruh setelah pemakaiannya dan keuntungan kontrasepsi tersebut.

Berdasarkan hasil analisis didapatkan bahwa responden terbanyak pada umur $<40$ tahun sebanyak 58 orang $(65.2 \%)$. Hal ini sejalan dengan teori Hartanto (2004), menyatakan bahwa usia 20-35 tahun merupakan fase menjarangkan kehamilan dan terbaik untuk mengandung dan melahirkan. Usia tersebut sesuai dengan usia yang disampaikan oleh Hurlock (1999), merupakan bagian dari masa dewasa awal dimulai umur 18 tahun sampai umur 40 tahun, terjadi perubahan fisik dan psikologis serta berkurangnya kemampuan reproduktif. Menurut pendapat peneliti, masa dewasa merupakan masa terjadi perubahan fisik (reproduktif) akan mengalami degradasi sedikit-demi sedikit, mengikuti umur seseorang hingga menjadi tua.

Berdasarkan hasil analisis didapatkan bahwa responden terbanyak pada status gizi yang normal sebanyak 56 orang $(62.9 \%)$. Hal ini sejalan dengan penelitian Marmi (2012), bila tubuh memperoleh cukup zat-zat gizi akan tercapai status gizi optimal yang memungkinkan pertumbuhan fisik dan kesehatan pada tingkat setinggi mungkin. Menurut pendapat peneliti, pertumbuhan normal tubuh memerlukan kecukupan energi, protein, lemak, dan suplai semua nutrien esensial untuk pertumbuhan sel atau jaringan, fungsi pemeliharanan maupun aktivitas tubuh dengan memiliki IMT (indeks masa tubuh) yang sesuai.

Berdasarkan hasil analisis didapatkan bahwa responden terbanyak pada aktivitas fisik aktif sebanyak 55 orang $(61.8 \%)$. Hal ini sejalan teori $d r$. Enud (2011), menyatakan bahwa ibu rumah tangga maupun perempuan karir dapat mengalami ketidaksuburan karena pola pekerjaan yang berat tiap hari yang menimbulkan kelelahan fisik dan psikologis yang dapat mempengaruhi otak dan terganggunya sistem hormonal (kelainan haid, penekanan produksi sel telur, penyempitan saluran telur). Sedangkan berdasarkan penelitian yang dilakukan oleh FKUI (2012) pada sekolah kepolisian perempuan, latihan fisik yang berat dan kurangnya waktu istirahat menyebabkan kelelahan dan stres yang mempengaruhi siklus haid menjadi tidak teratur atau bahkan jarang mendapatkan haid. Menurut pendapat peneliti, melakukan aktivitas fisik dapat mempengaruhi sistem tubuh yang menyebabkan tubuh stres hingga merusak kualitas sel-sel reproduksi.

Berdasarkan hasil analisis didapatkan bahwa responden terbanyak mengalami stress sebanyak 55 orang (61.8\%). Sejalan dnegan teori Psychology Foundation of Australia (2010), kondisi stress cenderung menjadi mudah marah, tidak fokus dan dapat memicu timbulnya rasa sakit kepala karena terjadi vasokontriksi pada pembuluh darah yang mengakibatkan perfusi oksigen ke jaringan berkurang (jaringaan otak) sehingga dapat menpengaruhi kemampuan dan orientasi terhadap kegiatan proses fisik dalam tubuh. Menurut pendapat peneliti, keadaan stress akan menyebabkan kemampuan kegiatan proses fisik dalam tubuh tergangggu karena tubuh perlu 
Tabel 4.2

Hubungan Kontrasepsi Hormonal dengan Jumlah perdarahan menstruasi di Rumah Bersalin Sri Nirmala

\begin{tabular}{|c|c|c|c|c|}
\hline \multirow[b]{2}{*}{ Kontrasepsi Hormonal } & \multicolumn{2}{|c|}{ Jumlah perdarahan menstruasi } & \multirow[b]{2}{*}{$\begin{array}{c}n \\
(\%)\end{array}$} & \multirow[b]{2}{*}{$\mathrm{P}$ value } \\
\hline & $\begin{array}{c}\text { Normal } \\
\mathrm{N}(\%)\end{array}$ & $\begin{array}{c}\text { Tidak Normal } \\
\mathrm{n}(\%)\end{array}$ & & \\
\hline Suntik & $\begin{array}{c}14 \\
(28.6 \%)\end{array}$ & $\begin{array}{c}35 \\
(71.4 \%)\end{array}$ & $\begin{array}{c}49 \\
(100 \%)\end{array}$ & \\
\hline Pil & $\begin{array}{c}11 \\
(44.0 \%)\end{array}$ & $\begin{array}{c}14 \\
(56.0 \%)\end{array}$ & $\begin{array}{c}25 \\
(100 \%)\end{array}$ & 0.026 \\
\hline Implan & $\begin{array}{c}10 \\
(66.7 \%)\end{array}$ & $\begin{array}{c}5 \\
(33.3 \%)\end{array}$ & $\begin{array}{c}15 \\
(100 \%)\end{array}$ & \\
\hline Total & $\begin{array}{c}35 \\
(39,3 \%)\end{array}$ & $\begin{array}{c}54 \\
(60,7 \%)\end{array}$ & $\begin{array}{c}89 \\
(100 \%)\end{array}$ & \\
\hline
\end{tabular}

melakukan penyesuaian terhadap stresor.

Berdasarkan tabel 4.2 didapatkan data bahwa distribusi frekuensi 89 orang responden dilakukan uji statistik dengan uji chi-square diperoleh nilai signifikan $\mathrm{p}$ value $=0,026$ artinya nilai $p$ value $<0,05$. Hal ini menunjukkan bahwa hipotesis Ho ditolak dan $\mathrm{H}_{1}$ diterima, secara statistik ada hubungan bermakna antara penggunaan kontrasepsi hormonal dengan jumlah perdarahan menstruasi. Penelitian ini sejalan dengan penelitian oleh Faridah (2005) yang menyimpulkan bahwa ada hubungan yang bermakna antara pemakaian alat kontrasepsi pil dan suntik dengan gangguan menstruasi di Desa Gentan Kecamatan Susukan Kabupaten Serang. Dan sesuai dengan penelitian Suratun (2009) yang menyatakan bahwa efek samping utama dari implant adalah perubahan pola haid yang terjadi pada kira-kira 60\% akseptor. Menurut pendapat peneliti, bahwa kontrasepsi hormonal sebagian besar mengalami rata-rata jumlah darah yang keluar sedikit, sesuai dengan kandungan dan dosis yang digunakan.

Berdasarkan tabel 4.3 didapatkan data bahwa distribusi frekuensi 89 orang responden dilakukan bagian test statistics dengan uji chisquare diperoleh nilai signifikan $p$ value $=$ 0.018 artinya nilai $p$ value $<0,05$. Hal ini menunjukkan bahwa hipotesis Ho ditolak dan $\mathrm{H}_{1}$ diterima, secara statistik ada perbedaan bermakna antara umur dengan jumlah perdarahan menstruasi menstruasi dan Odd Ratio (OR) 3.200, yang berarti bahwa ibu yang berumur $<40$ tahun berisiko 3.200 kali mengalami gangguan jumlah perdarahan menstruasi menstruasi. Hal ini sejalan dengan penelitian Pratiwi, S (2013), menunjukkan bahwa umur memiliki hubungan yang signifikan terhadap jumlah perdarahan menstruasi di Puskesmas Pakis Surabaya $(\rho=0,000)$ didapatkan usia < 20 tahun sebanyak 2 orang $(6,1 \%)$, usia 20-29 tahun sebanyak 13 orang (39,4\%), usia 30-39 tahun sebanyak 13 orang $(39,4 \%)$, usia 40-49 tahun sebanyak 4 orang $(12,1 \%)$, usia $>50$ tahun sebanyak 1 orang $(3,0 \%)$. Menurut pendapat peneliti, bahwa umur sangat mempengaruhi jumlah perdarahan menstruasi menstruasi terutama umur antara menarche ( $\leq 20$ tahun) mengalami gangguan lamanya siklus haid, atau jumlah dan lamanya menstruasi dan masa menopause ( $>45$ tahun) mengalami 
Tabel 4.3

Hubungan Umur dengan Jumlah Perdarahan Menstruasi di Rumah Bersalin Sri Nirmala

\begin{tabular}{|c|c|c|c|c|c|}
\hline \multirow[b]{2}{*}{ Umur } & \multicolumn{2}{|c|}{ Jumlah perdarahan menstruasi } & \multirow[b]{2}{*}{$\begin{array}{c}n \\
(\%)\end{array}$} & \multirow[b]{2}{*}{$\mathrm{P}$ value } & \multirow[b]{2}{*}{$\begin{array}{c}\text { OR } \\
(95 \% \mathrm{Cl})\end{array}$} \\
\hline & $\begin{array}{c}\text { Normal } \\
\mathrm{n}(\%)\end{array}$ & $\begin{array}{c}\text { Tidak Normal } \\
\mathrm{n}(\%)\end{array}$ & & & \\
\hline$<40$ tahun & $\begin{array}{c}28 \\
(48.3 \%)\end{array}$ & $\begin{array}{c}30 \\
(51.7 \%)\end{array}$ & $\begin{array}{c}58 \\
(100 \%)\end{array}$ & & 3.200 \\
\hline$\geq 40$ tahun & $\begin{array}{c}7 \\
(22.6 \%)\end{array}$ & $\begin{array}{c}24 \\
(77.4 \%)\end{array}$ & $\begin{array}{c}31 \\
(100 \%)\end{array}$ & 0.018 & $(1.193-8.586)$ \\
\hline Total & $\begin{array}{c}35 \\
(39,3 \%)\end{array}$ & $\begin{array}{c}54 \\
(60,7 \%)\end{array}$ & $\begin{array}{c}89 \\
(100 \%)\end{array}$ & & \\
\hline
\end{tabular}

masa menstruasi menjadi tidak teratur sampai timbulnya tanda-tanda menopause. Sehingga dapat disimpulkan semakin tinggi umur maka jumlah perdarahan menstruasi akan semakin tidak normal.

Berdasarkan tabel 4.4 didapatkan data bahwa distribusi frekuensi 89 orang responden dilakukan bagian test statistics dengan uji chisquare diperoleh nilai signifikan $p$ value $=$ berisiko 3.714 kali mengalami gangguan jumlah perdarahan menstruasi. Penelitian ini sesuai dengan penelitian Felicia dkk (2015), menunjukkan bahwa dari 67 responden, ada 9 responden $(33,3 \%)$ yang memiliki status gizi kurus dengan siklus menstruasi teratur, 6 responden $(20,7 \%)$ yang memiliki status gizi normal dengan siklus menstruasi tidak teratur, dan 2 responden $(18,2 \%)$ yang memiliki status gizi gemuk dengan siklus

Tabel 4.4

Hubungan Status Gizi dengan Jumlah Perdarahan Menstruasi di Rumah Bersalin Sri Nirmala

\begin{tabular}{|c|c|c|c|c|c|}
\hline \multirow[t]{2}{*}{ Status Gizi } & \multicolumn{2}{|c|}{$\begin{array}{l}\text { Jumlah perdarahan } \\
\text { menstruasi }\end{array}$} & \multirow{2}{*}{$\begin{array}{c}n \\
(\%)\end{array}$} & \multirow[t]{2}{*}{$P$ value } & \multirow{2}{*}{$\begin{array}{c}\text { OR } \\
(95 \% \mathrm{Cl})\end{array}$} \\
\hline & $\begin{array}{c}\text { Normal } \\
\mathrm{n}(\%)\end{array}$ & $\frac{\text { Tidak Normal }}{\mathrm{N}(\%)}$ & & & \\
\hline $\begin{array}{c}\text { Normal } \\
(18,5-25,0)\end{array}$ & $\begin{array}{c}28 \\
(50.0 \%)\end{array}$ & $\begin{array}{c}28 \\
(50.0 \%)\end{array}$ & $\begin{array}{c}56 \\
(100 \%)\end{array}$ & & 3.714 \\
\hline $\begin{array}{c}\text { Tidak Normal } \\
(<17,0 \text { atau } \geq 25)\end{array}$ & $\begin{array}{c}7 \\
(21.2 \%)\end{array}$ & $\begin{array}{c}26 \\
(78.8 \%)\end{array}$ & $\begin{array}{c}33 \\
(100 \%)\end{array}$ & 0.007 & $(1.387-9.950)$ \\
\hline Total & $\begin{array}{c}35 \\
(39,3 \%)\end{array}$ & $\begin{array}{c}54 \\
(60,7 \%)\end{array}$ & $\begin{array}{c}89 \\
(100 \%)\end{array}$ & & \\
\hline
\end{tabular}

0.007 artinya nilai $p$ value $<0,05$. Hal ini menunjukkan bahwa hipotesis Ho ditolak dan $\mathrm{H}_{1}$ diterima, secara statistik ada perbedaan bermakna antara status gizi dengan jumlah perdarahan menstruasi dan Odd Ratio (OR) 3.174 yang berarti bahwa ibu yang berstatus gizi normal menstruasi teratur. Setelah dilakukan pengolahan data dengan menggunakan uji Chi Square didapatkan hasil yaitu $p=$ $0,000<0,05$. Menunjukkan bahwa ada hubungan yang bermakna antara status gizi dengan siklus menstruasi pada remaja putri di PSIK FK UNSRAT 
Tabel 4.5

Hubungan Aktivitas Fisik dengan Jumlah Perdarahan Menstruasi di Rumah Bersalin Sri Nirmala

\begin{tabular}{|c|c|c|c|c|c|}
\hline \multirow[t]{2}{*}{ Aktivitas Fisik } & \multicolumn{2}{|c|}{$\begin{array}{c}\text { Jumlah perdarahan } \\
\text { menstruasi }\end{array}$} & \multirow{2}{*}{$\begin{array}{c}\mathrm{n} \\
(\%)\end{array}$} & \multirow[t]{2}{*}{$P$ value } & \multirow{2}{*}{$\begin{array}{c}\text { OR } \\
(95 \% \mathrm{Cl})\end{array}$} \\
\hline & $\begin{array}{c}\text { Normal } \\
\mathrm{n}(\%)\end{array}$ & $\begin{array}{c}\text { Tidak Normal } \\
\mathbf{N}(\%)\end{array}$ & & & \\
\hline Tidak Aktif & $\begin{array}{c}8 \\
(23.5 \%)\end{array}$ & $\begin{array}{c}26 \\
(76,5 \%)\end{array}$ & $\begin{array}{c}35 \\
(100 \%)\end{array}$ & & \\
\hline Aktif & $\begin{array}{c}27 \\
(49.1 \%)\end{array}$ & $\begin{array}{c}28 \\
(50.9 \%)\end{array}$ & $\begin{array}{c}54 \\
(100 \%)\end{array}$ & 0.016 & $\begin{array}{c}0.319 \\
(0.123-0.827)\end{array}$ \\
\hline Total & $\begin{array}{c}35 \\
(39.3 \%)\end{array}$ & $\begin{array}{c}54 \\
(60.7 \%)\end{array}$ & $\begin{array}{c}89 \\
(100 \%)\end{array}$ & & \\
\hline
\end{tabular}

Manado. Menurut pendapat peneliti, bahwa terlihat apabila memiliki asupan gizi yang baik membuat kerja hipotalamus menjadi baik sehingga bisa memproduksi hormon-hormon yang dibutuhkan tubuh terutama hormon reproduksi, sehingga jumlah perdarahan menstruasi bisa menjadi normal.

Berdasarkan tabel 4.5 didapatkan data bahwa distribusi frekuensi 89 orang responden dilakukan bagian test statistics dengan uji chisquare diperoleh nilai signifikan $\mathrm{p}$ value $=$ 0.016 artinya nilai $p$ value $<0,05$. Hal ini bahwa ibu yang melakukan aktivitas fisik aktif berisiko 0.139 kali mengalami gangguan jumlah perdarahan menstruasi. Penelitian ini sejalan dengan penelitian Liu Y dkk (2004) di California bahwa wanita berusia kurang dari 35 tahun dengan aktivitas fisik $>4$ jam per minggu akan memperpanjang fase folikuler. Sedangpan pada penelitian Nattiv A dkk (2007) di Patras University Medical School menyatakan jika melakukan aktivitas fisik selama 15 jam atau lebih setiap minggunya atau intensitas aktivitas fisik yang terlalu tinggi akan tidak mampu

Tabel 4.6

Hubungan Keadaan Stress dengan Jumlah Perdarahan Menstruasi di Rumah Bersalin Sri Nirmala

\begin{tabular}{|c|c|c|c|c|c|}
\hline \multirow[b]{2}{*}{$\begin{array}{l}\text { Keadaan } \\
\text { Stress }\end{array}$} & \multicolumn{2}{|c|}{ Jumlah perdarahan menstruasi } & \multirow[b]{2}{*}{$\begin{array}{c}n \\
(\%)\end{array}$} & \multirow[b]{2}{*}{$\mathrm{P}$ value } & \multirow[b]{2}{*}{$\begin{array}{c}\text { OR } \\
(95 \% \mathrm{Cl})\end{array}$} \\
\hline & $\begin{array}{c}\text { Normal } \\
\mathrm{n}(\%)\end{array}$ & $\begin{array}{c}\text { Tidak Normal } \\
\mathrm{n}(\%)\end{array}$ & & & \\
\hline Stress & $\begin{array}{c}27 \\
(49.1 \%)\end{array}$ & $\begin{array}{c}28 \\
(50.9 \%)\end{array}$ & $\begin{array}{c}55 \\
(100 \%)\end{array}$ & & 3.134 \\
\hline Normal & $\begin{array}{c}8 \\
(23.5 \%)\end{array}$ & $\begin{array}{c}26 \\
(76.5 \%)\end{array}$ & $\begin{array}{c}34 \\
(100 \%)\end{array}$ & 0.016 & $(1.209-8.124)$ \\
\hline Total & $\begin{array}{c}35 \\
(39,3 \%)\end{array}$ & $\begin{array}{c}54 \\
(60,7 \%)\end{array}$ & $\begin{array}{c}89 \\
(100 \%)\end{array}$ & & \\
\hline
\end{tabular}

menunjukkan bahwa hipotesis Ho ditolak dan $\mathrm{H}_{1}$ diterima, secara statistik ada perbedaan bermakna antara aktivitas fisik dengan jumlah perdarahan menstruasi dan Odd Ratio (OR) 0.139 yang berarti dikompensasi oleh tubuh dapat menyebabkan gangguan endokrin dalam tubuh salah satunya ketidakteraturan siklus menstruasi (Jorge EC dkk, 2008). Menurut pendapat peneliti, aktivitas fisik 
yang berlebihan bisa menyebabkan siklus menstruasi terganggu (hormon hipofisis yang menyebabkan pengaruh ovulasi (pelepasan sel telur) dan mempengaruhi hipotalamus, juga mempengaruhi hormon menstruasi. Ovulasi ini mempengaruhi menstruasi tidak akan mulus.

Berdasarkan tabel 4.6 didapatkan data bahwa distribusi frekuensi 89 orang responden dilakukan bagian test statistics dengan uji chisquare diperoleh nilai signifikan $\mathrm{p}$ value $=$ 0.016 artinya nilai $p$ value $<0,05$. Hal ini menunjukkan bahwa hipotesis Ho ditolak dan $\mathrm{H}_{1}$ diterima, secara statistik ada perbedaan bermakna antara stress dengan jumlah perdarahan menstruasi dan Odd Ratio (OR) 3.134 yang berarti bahwa ibu yang mengalami stress berisiko 3.134 kali mengalami gangguan jumlah perdarahan menstruasi. Penelitian ini sejalan dengan penelitian Saaerang A, dkk (2014), menunjukkan ada hubungan antara tingkat stres dengan siklus haid pada mahasiswi Fakultas Kedokteran Universitas Sam Ratulangi Manado dengan nilai $p$ value 0,286 . Sejalan dengan penelitian Toduho (2014) terdapat hubungan yang signifikan antara stress psikologik dengan siklus menstruasi dengan nilai $p$-value 0,000 . Menurut pendapat peneliti, hormon stres (kortisol) berdampak pada jumlah estrogen dan progesteron dalam tubuh. Jumlah hormon yang terlalu banyak dalam darah bisa menyebabkan perubahan siklus menstruasi.

\section{KESIMPULAN DAN SARAN}

Secara statistik dapat disimpulkan bahwa ada hubungan bermakna antara kontrasepsi hormonal, umur, status gizi, aktivitas fisik, dan stress dengan jumlah perdarahan menstruasi. Pelayanan kesehatan yang dekat dengan masyarakat seperti Bidan, Perawat, Puskesmas dan Posyandu hendaknya untuk lebih meningkatkan kegiatan seperti konseling, penyuluhan kesehatan, dan KIE terkait efek samping kontrasepsi hormonal.

\section{DAFTAR PUSTAKA}

Badan Keluarga Berencana Dan Pemberdayaan Perempuan Kota Palembang. (2016). Laporan Rekapitulasi Tahunan. Sumatera Selatan: Palembang

Bidan Praktik Sri Nirmala. (2016). Laporan Rekapitulasi Tahunan. Kalidoni

BKKBN. (2002). Buku Sumber untuk Advokasi. BKKBN dan UNFPA.

. (2013). Buku Acuan Implan-2 untuk Program Keluarga Berencana Tentang Delapan

Penatalaksanaan Efek Samping Dan Masalah Kesehatan Lainnya. Jawa Tengah.

(2015). Rencana Strategis Badan Kependudukan Dan Keluarga Berencana Nasional Tahun 2015 2019. Jakarta

Dinas Kesehatan Kota Palembang. (2014). Profil Kesehatan Kota Palembang Tahun 2014. Palembang.

Faridah. (2005). Perbedaan Pola Menstruasi Antara Pemakaian Alat Kontra-sepsi Pil dan Suntik di Desa Gentan Kecamatan Susukan Kabupaten Serang. Semarang: FKM UNDIP.

Felicia, dkk. (2015). Hubungan Status Gizi Dengan Siklus Menstruasi Pada Remaja Putri Di PSIK FK UNSRAT Manado, 3 (1), 1-4. 
Universitas Sam Ratulangi
Manado.

Glasier, A. dan Gebbie, A. (2005). Keluarga Berencana \& Kesehatan Reproduksi. Jakarta : EGC

Hartanto, H. (2004). Keluarga Berencana dan Kontrasepsi. Jakarta: Sinar Harapan.

Hurlock, E. B.(1993). Psikologi Perkembangan: Suatu pendekatan sepanjang rentang kehidupan (edisi kelima). Jakarta: Erlangga

Saerang, Anster. (2014). Hubungan Antara Stres Dengan Pola Menstruasi Pada Mahasiswi Fakultas Kedokteran Universitas Sam Ratulangi Manado Angkatan 2010, 2 (3), 1-3. Universitas Sam Ratulangi Manado: Jurnal e-Clinic (eCl).

Toduho, S., dkk. (2014). Hubungan Stres Psikologis Dengan Siklus Menstruasi Pada Siswi Kelas 1 Di SMA Negeri 3 Tidore Kepulauan. Universitas Sam Ratulangi Manado.

Smeltzer, S.C. dan Bare, B. G. (2008). Brunner and Sudarth's textbook of medical-surgical nursing, terjemah.Agung. Jakarta: EGC

Pratiwi, A. (2013). Hubungan Status Gizi dengan Keteraturan Siklus
Menstruasi Siswi SMA Negeri 1 Mojolaban. Universitas Sebelas Maret: Karya Tulis IImiah.

Pratiwi, S. N. (2013). Hubungan Pemakaian Metode Kontrasepsi Dengan Perubahan Siklus Menstruasi pada Ibu Usia Produktif di Puskesmas Pakis Surabaya. Sekolah Tinggi IImu Kesehatan HangTuah Surabaya

Pristina, dkk (2015). Hubungan Asupan Zat Gizi, Aktivitas Fisik, Dan Persentase Lemak Tubuh Dengan Gangguan Siklus Menstruasi Pada Penari, 4 (1), 39-49. Universitas Dipenegoro

Yani, N. G. (2016). Hubungan Aktivitas Fisik Dengan Siklus Menstruasi Pada Atlet Kontingen PON XIX Jawa Barat Di Koni Sulawesi Selatan. Universitas Hasanuddin: Skripsi

World Health Organization (WHO). (1994). Improving Access to Quality Care in Family Planning: Eligibility Criteria for Initiating Use of Selected Methods of Contraception. Draft Report, November

- (2010); Physical Activity. In Guide to Community Preventive Services Website, 2008. 